\title{
Finding Prejudice: Ineffective Assistance of Counsel in Lee $v$. United States
}

Journal of Criminal Justice and Law

Volume 2, Issue 1, pp. 51-67 (2018)

\section{Michelle M. Watson ' and Melanie K. Worsley "}

\begin{abstract}
This paper discusses the 2017 case of Lee v. United States, in which the U.S. Supreme Court held for the first time that a defendant had been prejudiced by his counsel's misinformation about the deportation consequences of a guilty plea. The Lee case marks a significant step in the Court's recognition of ineffective assistance of counsel claims and criminal defendants' right to receive accurate legal advice when deciding whether to accept a plea offer. The Court's journey to Lee is examined, beginning with its declaration in 1985 that the test for ineffective assistance of counsel claims, established in Strickland $v$. Washington, applies in the context of plea bargains. The possible implications of Lee are also considered, including reflection on language in the case that appears to provide for widespread relief to defendants but which could conversely lead to a narrow interpretation and application of Lee.
\end{abstract}

\section{Keywords}

Prejudice, ineffective assistance of counsel, deportation, immigration, plea bargain, Sixth Amendment

\section{Introduction}

In the 2017 decision of Lee v. United States, the U.S. Supreme Court addressed the prejudicial effect of defense counsel's misinformation about the deportation consequences

\footnotetext{
' Criminal Justice and Legal Studies Department, Washburn University, Topeka, KS, USA

" Criminal Justice and Legal Studies Department, Washburn University, Topeka, KS, USA
}

\section{Corresponding Author:}

Michelle M. Watson, Criminal Justice and Legal Studies Department, Washburn University, 1700 College Ave., Benton Hall, Room 203A, Topeka, KS, 66621, USA

E-mail: michelle.watson@washburn.edu

The authors wish to express their appreciation to the blind reviewers of the original manuscript for their comments, which were helpful during preparation of the final version of the manuscript. 
of a defendant's guilty plea in a criminal case. ${ }^{1}$ This case marks a significant step in the Supreme Court's recognition of ineffective assistance of counsel claims and a defendant's right to receive accurate legal advice when deciding whether to accept a plea offer or to reject the offer and proceed to trial, even when the possibility of a favorable trial outcome is slim to none. More than $95 \%$ of criminal cases end in plea agreements, which means that a vast number of defendants rely on their attorneys' advice in waiving the privilege of going to trial. ${ }^{2}$ Although most defense attorneys are not likely to be well versed on immigration laws and although the "collateral" consequences of a guilty plea are not an integrated part of the guilt phase of a trial, the Court has placed an affirmative duty on defense counsel to warn clients of mandatory deportation. ${ }^{3}$ This duty has been in existence since the Court's 2010 decision in Padilla v. Kentucky, but before Lee, the Court had never made a finding of prejudice in this context. ${ }^{4}$

\section{Right to Effective Assistance of Counsel}

In arriving at the Lee decision, the U.S. Supreme Court's journey has been long and circuitous. Claims of ineffective assistance of counsel have spanned a wide expanse that encompasses "critical stages" of the prosecution of criminally accused individuals. ${ }^{5}$ The right to effective counsel evolved out of the right to counsel found in the Sixth Amendment to the U.S. Constitution, which guarantees every criminal defendant "shall enjoy the right to ... have the assistance of counsel for his defense." ${ }^{\text {"T }}$ The Supreme Court has interpreted this Sixth Amendment provision to mean that individuals must be informed of their right to counsel before a custodial interrogation and must be protected against ineffective assistance of counsel. The right to assistance of counsel also means that the government must provide defense counsel for indigent defendants in criminal cases. The Supreme Court has stressed that assistance of counsel is a constitutional principle essential to ensuring a fair trial. ${ }^{7}$ However, the term "critical stages" has been deemed to include a variety of judicial proceedings, including, in part, pretrial hearings, entry of guilty pleas, trials, and sentencing. ${ }^{8}$ Our focus is on effective assistance of counsel during the plea process - the point in time during which most criminal cases end.

\section{Two-Part Strickland Test}

To understand the holding in Lee, it is helpful to follow the U.S. Supreme Court's path to finding prejudice caused by defense counsel's performance. It was not until the 1984 case of Strickland $v$. Washington that the Supreme Court established a bright-line rule for

\footnotetext{
${ }^{1}$ Lee v. United States, 137 S. Ct. 1958 (2017).

2 Claire Bernish, Due Process is Dead: A Staggering 95\% of All Inmates in America Have Never Received a Trial, Jan. 25, 2016, http://thefreethoughtproject.com/due-process-dead-staggering-95inmates-america-received-trial/; see

Erica Goode, Stronger Hand for Judges in the "Bazaar" of Plea Deals, N.Y. TIMEs (Mar. 22, 2012), http://www.nytimes.com/2012/03/23/us/stronger-hand-for-judges-after-rulings-on-plea-deals.html.

${ }^{3}$ See Jenny Roberts, Proving Prejudice, Post-Padilla, 54 How. L.J. 693, 694 (Spring 2011).

${ }^{4}$ Padilla v. Kentucky, 559 U.S. 356 (2010).

${ }^{5}$ Montejo v. Louisiana, 556 U.S. 778, 786 (2009).

${ }^{6}$ U.S. CONST. amend. VI.

7 Gideon v. Wainwright, 372 U.S. 335, 344-45 (1963).

${ }^{8}$ Lafler v. Cooper, 566 U.S. 156, 165 (2012); United States v. Wade, 388 U.S. 218, 226-27 (1967).
} 
addressing ineffective assistance of counsel claims. ${ }^{9}$ The defendant, who received the death penalty, sought relief on numerous grounds, one of which alleged that defense counsel's assistance had been deficient at the sentencing hearing. The Supreme Court noted that counsel's role in a capital sentencing proceeding is "comparable to counsel's role at trial—to ensure that the adversarial testing process works to produce a just result under the standards governing decision." ${ }^{10}$ A defendant who claims that counsel's assistance was so defective as to require the reversal of a conviction or sentence must satisfy the requirements of a two-prong test, showing that (1) counsel's performance was deficient and (2) the deficiency prejudiced the defense. ${ }^{11}$ The first prong ties into the practice and expectations of the legal community, requiring counsel's performance to be reasonable under "prevailing professional norms." ${ }^{12}$ To be considered deficient, the conduct must essentially amount to incompetence, which is different from a mere deviation from "best practices or most common custom." ${ }^{13}$ Moreover, courts must examine the reasonableness of counsel's challenged conduct as of the time it occurred, in light of the facts and circumstances of the case in question.

Under the second, prejudice prong of the Strickland test, a defendant must demonstrate that but for the constitutionally deficient representation, there is a reasonable probability that the result of the proceeding would have been different. A reasonable probability means a "probability sufficient to undermine confidence in the outcome." 14 The prejudice prong can understandably be a difficult hurdle to overcome, and the Supreme Court has cautioned that the "likelihood of a different result must be substantial, not just conceivable." ${ }^{15}$ At the time of Strickland, the Court had not yet addressed any claims of deficient performance of attorneys during the plea-bargaining stage of a case, but one year after Strickland, this topic was presented before the Court, initially through the case of Hill v. Lockhart ${ }^{16}$ and subsequently through several other cases in the Court's journey to Lee.

\section{Application of Strickland in Pre-Lee Plea Bargain Cases}

Because the plea-bargaining stage takes place before trial, the prejudice prong of the Strickland test-requiring the defendant to show that but for counsel's deficiencies, the result of the proceeding would have been different-does not fit neatly into the analysis of an ineffective assistance claim. In Hill v. Lockhart, the U.S. Supreme Court not only established for the first time that Strickland applies to the plea-bargaining stage but also addressed how to apply the prejudice prong to a plea bargain case. ${ }^{17}$ The effect of Hill was immense in the criminal defense arena, where plea bargains are plentiful.

In Hill, an incarcerated individual, William Lloyd Hill, had filed a post-conviction petition, claiming that his guilty plea was involuntary as the result of ineffective assistance of defense counsel during the underlying Arkansas criminal case, in which he had pleaded

${ }^{9}$ Strickland v. Washington, 466 U.S. 668 (1984).

10 ld. at 686 .

11 Id. at 687.

12 See Flynn v. State, 281 Kan. 1154, 1162-63 136 P.3d 909 (2006).

${ }^{13}$ Harrington v. Richter, 562 U.S. 86, 105 (2011) (citing Strickland, 466 U.S. at 690).

14 United States v. Strickland, 466 U.S. 668, 694 (1984).

15 Harrington, 562 U.S. at 111; see Strickland, 466 U.S. at 691.

${ }^{16}$ Hill v. Lockhart, 474 U.S. 52 (1985).

17 Id. at 58-59. 
guilty to first-degree murder and theft of property. ${ }^{18}$ According to Hill, defense counsel had failed to advise him that the state sentencing statutes required the defendant, as a second offender, to serve one-half of his sentence before becoming eligible for parole. ${ }^{19}$ Instead, defense counsel had informed him that his guilty plea would result in parole eligibility after completion of only one-third of his sentence. The federal district court denied Hill's request for relief without a hearing, and the U.S. Court of Appeals for the Eighth Circuit affirmed. ${ }^{20}$ Because the Hill case conflicted with the result in a similar case in the U.S. Court of Appeals for the Fourth Circuit, the U.S. Supreme Court granted certiorari. ${ }^{21}$

The Supreme Court first noted the well-known test for determining the validity of a guilty plea, which asks "whether the plea represents a voluntary and intelligent choice among the alternative courses of action open to the defendant."22 However, Hill did not argue that the State's failure to furnish him with parole eligibility information had rendered his plea involuntary. ${ }^{23}$ Rather, Hill attacked defense counsel's failure to inform him accurately of parole eligibility, so the Supreme Court was tasked with determining whether Strickland would apply in this context. The Court observed that in a case in which a defendant pleads guilty on advice of counsel, "the voluntariness of the plea," as established in McMann v. Richardson, ${ }^{24}$ "depends on whether counsel's advice 'was within the range of competence demanded of attorneys in criminal cases."'25 The McMann test was premised on the principle that criminal defendants-at that time offenders facing felony charges-are entitled to effective assistance of counsel. Because of this right, from which stemmed the Strickland test for ineffective assistance in the context of criminal trials, the Court concluded that Strickland should apply to the plea process as well.

The Supreme Court specified that its reasons for imposing the prejudice prong in Strickland to a capital sentencing proceeding should also apply in the context of guilty pleas. One of these reasons included the fact that "[t]he government is not responsible for, and hence not able to prevent, attorney errors that will result in the reversal of a conviction or sentence."26 Attorney errors appear in such a variety that, no matter the context, it is impossible to provide defense attorneys with an exact description or definition of what constitutes prohibited conduct. ${ }^{27}$ Further, in light of the large number of guilty pleas, the

\footnotetext{
18 Id. at 53-54.

19 Id. at 52; Ark. Stat. Ann. § 43-2829 B(3) (1977). Under Arkansas statutes, an offender convicted of first-degree murder would potentially serve 5- to 50-years' imprisonment or life imprisonment. Hill's appointed counsel negotiated a plea agreement in which Hill would plead guilty to murder and theft, and in exchange, the State would recommend concurrent prison sentences of 35 years (murder) and 10 years (theft).

20 Hill, 474 U.S. at 55.

${ }^{21}$ Id. at 53 (citing Strader v. Garrison, 611 F.2d 61 (4th Cir. 1979)).

22 Hill v. Lockhart, 474 U.S. 52, 56 (1985) (quoting North Carolina v. Alford, 400 U.S. 25, 31

(1970)).

${ }^{23}$ Id. (citing FED. R. CRIM. P. 119(c); then citing FED R. CRIM. P. 11 advisory committee's notes to 1974 amendment). Federal courts are generally not required to inform a defendant about parole eligibility before accepting a guilty plea.

24 McMann v. Richardson, 397 U.S. 759 (1970).

${ }^{25}$ Hill, 474 U.S. 52, 56 (1985) (quoting McMann, 397 U.S. at 771).

${ }^{26}$ Id. at 57.

${ }^{27}$ Id. at 57-58 (1985) (citing United States v. Strickland, 466 U.S. 668, 693 (1984)).
} 
Court indicated that requiring defendants to show prejudice serves a fundamental interest in the finality of those pleas. ${ }^{28}$

As for the application of the two-part Strickland test, the Hill Court stated that the first prong is the same in the context of a plea bargain. The second, prejudice prong, however, focuses not on the ineffectiveness of defense counsel during a trial but on "whether counsel's constitutionally ineffective performance affected the outcome of the plea process." 29 Under this rationale, a defendant must show that "there is a reasonable probability that, but for counsel's errors, he would not have pleaded guilty and would have insisted on going to trial." ${ }^{30}$ The Supreme Court noted that depending on the facts of a case, the prejudice analysis in a plea bargain case could look quite similar to the analysis in a case alleging ineffective assistance of counsel during trial-involving an objective prediction of the possible outcome. The Court compared the plea bargain situation to one in which a defendant attacks counsel's effectiveness because of the failure to investigate or discover potentially exculpatory evidence or the failure to inform the defendant of affirmative defenses. Under those scenarios, a court would examine whether the evidence or affirmative defense would likely have changed the trial's outcome. ${ }^{31}$

The Hill Court declined to address "whether there may be circumstances under which erroneous advice by counsel as to parole eligibility may be deemed constitutionally ineffective assistance of counsel," leaving that determination for another day. ${ }^{32}$ Nevertheless, the Court did find that Hill failed to satisfy the prejudice prong of Strickland because nowhere in Hill's post-conviction petition had he alleged that if counsel had accurately advised him about his parole eligibility date, he would have foregone a guilty plea and sought a trial. It was significant that Hill had not placed any emphasis on his parole eligibility as a determinative factor in making his decision to plead guilty. ${ }^{33}$ The Court continued to place a defendant's motivation, the determinative factor, under its microscope in the other cases leading up to Lee.

Fifteen years after Hill, in the split decision of Padilla v. Kentucky, ${ }^{34}$ the U.S. Supreme Court again addressed the application of Strickland to the plea process. Padilla is particularly important in our discussion of Lee because it ultimately established that defense counsel's advice regarding deportation falls under the ambit of the Sixth Amendment right to counsel, and thus counsel must provide adequate assistance not only by giving deportation advice to the defendant but also by giving him accurate advice.

${ }^{28}$ Hill v. Lockhart, 474 U.S. 52, 58 (1985) (citing United States v. Timmreck, 441 U.S. 780, 784 (1979) ("'Every inroad on the concept of finality undermines confidence in the integrity of our procedures. . . . The impact is greatest when new grounds for setting aside guilty pleas are approved ...."').

${ }^{29}$ Id. at 58-59; see Tollett v. Henderson, 411 U.S. 258 (1973).

30 Hill, 474 U.S. at 59.

31 Id. at $59-60$.

${ }^{32} I d$. at 60.

${ }^{33}$ Id. In Justice White's concurring opinion, he opined that counsel was not deficient because Hill never asserted that his attorney knew about his prior Florida felony conviction, which elevated the Arkansas sentence. Without such knowledge, counsel could not be expected to take that prior conviction into consideration when advising his client of the potential sentence. Id. at 61-63 (White, J. concurring).

${ }^{34}$ Padilla v. Kentucky, 559 U.S. 356 (2010). 
The defendant, Jose Padilla, a native of Honduras, had been living in the United States as a lawful permanent resident for over 40 years. He pleaded guilty to transporting a large quantity of marijuana. Under federal law, Padilla faced mandatory deportation because of this plea. He sought post-conviction relief on the basis that defense counsel had misinformed him about the consequences of his plea, advising the defendant that he "did not have to worry about immigration status since he had been in the country for so long." 35 In his petition, Padilla claimed that he would have chosen to go to trial if counsel had advised him correctly. The Kentucky Supreme Court denied relief without an evidentiary hearing, holding that the right to effective assistance of counsel does not protect an individual from erroneous deportation advice because deportation is merely a "collateral" consequence of a criminal conviction in that the sentencing court does not impose deportation. ${ }^{36}$ The U.S. Supreme Court granted certiorari to determine whether "as a matter of federal law, Padilla's counsel had an obligation to advise him that the offense to which he was pleading guilty would result in his removal from this country." ${ }^{37}$ The Court answered this question in the affirmative. ${ }^{38}$

The majority opinion, written by Justice Stevens, declined to make a distinction between collateral or direct consequences with regard to deportation because deportation is such a severe penalty and because "its close connection to the criminal process [makes it] uniquely difficult to classify as either a direct or collateral consequence." 39 Moreover, the influence of prevailing professional norms suggests that defense counsel must advise the client regarding the risk of deportation. ${ }^{40}$ To bolster this rationale, the Supreme Court noted that several years prior, in INS v. St. Cyr, ${ }^{41}$ it had recognized that a person's right to remain in this country could be more important to that person than any jail sentence. In addition, even though deportation proceedings are civil in nature, deportation is "intimately related to the criminal process." 42

Recognizing that immigration laws can be complex, the Padilla Court indicated that in instances in which immigration laws are not clear, a criminal defense attorney must merely advise a non-citizen client that "pending criminal charges may carry a risk of adverse

\footnotetext{
35 Id. at 359 (quoting Commonwealth v. Padilla, 253 S.W.3d 482, 483 (Ky. 2008)).

36 Id. at 359-60.

37 Id. at 360

38 Later, in Chaidez v. United States, 568 U.S. 342, 358 (2013), the Court ruled that Padilla does not apply retroactively.

39 Padilla, 559 U.S. at 366.

40 Padilla v. Kentucky, 559 U.S. 356, 367 (2010); see, e.g., ABA STANDARDS FOR CRIMINAL JUSTICE, PROSECUTION Function \& DeF. Function § 4-5.1(a), p. 197 (3d ed. 1993); ABA StANDARDS FOR CRIMINAL JUSTICE, PLEAS OF GUILTY §14-3.2(f), p. 116 (3d ed. 1999). Justice Alito, in his concurring opinion, thought that an attorney must refrain from "unreasonably providing incorrect advice" and must advise a defendant that a criminal conviction "may have adverse immigration consequences and that, if the alien wants advice on this issue, the alien should consult with an immigration attorney." Padilla, 559 U.S. at 375 (Alito, J., concurring). Justice Scalia's dissent opined that deportation is a collateral consequence of a criminal conviction, and, therefore, defense attorneys should not be considered inadequate for giving affirmative misadvise about such consequences. "We have never held, as the logic of the Court's opinion assumes, that once counsel is appointed all professional responsibilities of counsel-even those extending beyond defense the prosecution-become constitutional commands." Id. at 390 (Scalia, J. dissenting).

41 INS v. St. Cyr, 533 U.S. 289 (2001).

42 Padilla, 559 U.S. at 365 (citing INS v. Lopez-Mendoza, 468 U.S. 1032, 1038 (1984)).
} 
immigration consequences." 43 The Supreme Court rejected the notion that Strickland applies only to affirmative misadvice: "It is quintessentially the duty of counsel to provide her client with available advice about an issue like deportation and the failure to do so "clearly satisfies the first prong of the Strickland analysis." 44 The statute applicable to Padilla succinctly and clearly provided that a plea to his specific offense required deportation. ${ }^{45}$ Thus, because of the clear language, defense counsel's failure to give proper advice amounted to ineffective assistance in violation of the first prong of the Strickland test. ${ }^{46}$ The Court did not address the prejudice prong of the test, however. Instead, the Court reversed and remanded the case to the Kentucky Supreme Court for further proceedings in which Padilla would have the opportunity to demonstrate prejudice. ${ }^{47}$

In the concurring opinion, Justice Alito, joined by Chief Justice Stevens, suggested that the majority dramatically departed from precedent by requiring defense attorneys to advise clients of more than the "direct consequences of a criminal conviction." ${ }^{48} \mathrm{He}$ was troubled by the fact that the majority would require defense attorneys, who typically lack expertise in the immigration arena, to provide deportation advice. Justice Alito feared that defendants could be misled about what he characterized as a "collateral" consequence. ${ }^{49}$ The majority's decision, according to Justice Alito, "marks a major upheaval in Sixth Amendment law" because the majority cited no case law holding that defense counsel's failure to provide advice about "removal consequences of a criminal conviction" violates a defendant's constitutional right to counsel. ${ }^{50}$ However, Justice Alito agreed that "unreasonable and incorrect information" may constitute ineffective assistance and suggested that a defendant's constitutional right to counsel is satisfied if defense counsel informs the client that there might be consequences under immigration laws and that the client should consult an immigration specialist for specifics. ${ }^{51}$

The dissent, authored by Justice Scalia and joined by Justice Thomas, disagreed with the majority's conclusion that the Sixth Amendment requires defense counsel to provide "accurate advice concerning the potential removal consequences of a guilty plea." 52 Consequently, although the dissent agreed with the concurrence that deportation is a collateral consequence of a criminal conviction, the dissent disagreed with the notion that an attorney's affirmative misadvice regarding deportation constitutes ineffective assistance. Justice Scalia opined that there was no basis to extend "the constitutionally required advice regarding guilty pleas beyond those matters germane to the criminal prosecution at hand-to wit, the sentence that the plea will produce, the higher sentence

43 Id. at 369.

44 Id. at 371 (quoting Hill v. Lockhart, 474 U.S. 52, 62 (1985)).

45 Id. at 368; see 8 U.S.C.A. $\S 1227(\mathrm{a})(2)(B)(i)$ (2008) ("Any alien who at any time after admission has been convicted of . . . any law of regulation of a State, the United States or a foreign country relating to a controlled substance...., other than a single offense involving possession for one's own use of 30 grams or less of marijuana, is deportable.").

46 Padilla v. Kentucky, 559 U.S. 356, 369 (2010).

47 Id. at 374.

${ }^{48} \mathrm{Id}$. at 376. (Alito, J., concurring).

$49 \mathrm{Id}$. at 381-82. There could be circumstances in which an alien, as a consequence of entering a guilty plea, would not be deported but would be excluded from reentering the United States if he were to visit his home country.

50 Id. at 383.

51 Id. at 384, 388.

52 Padilla v. Kentucky, 559 U.S. 356, 388 (2010) (Scalia, J., dissenting). 
that conviction after trial might entail, and the chances of such a conviction." ${ }^{53}$ Thus, he would limit a defense attorney's obligations. ${ }^{54}$

The following year, in Premo v. Moore, the U.S. Supreme Court again addressed a claim of ineffective assistance of counsel during the plea process. ${ }^{55}$ This time, the focus was not on deportation advice but on plea advice given without counsel's having first sought to exclude the defendant's confession to law enforcement officers. In the underlying Oregon case, Randy Moore pleaded no contest to felony murder in exchange for 300 months' incarceration, the minimum sentence for the offense. Moore admitted his involvement in the crime to two individuals and then repeated the same account of events to law enforcement. ${ }^{56}$

Moore then sought post-conviction relief in state court. At an evidentiary hearing, defense counsel explained that he had told Moore the court would likely deny a motion to suppress statements to police because of Moore's prior confessions. Counsel had also spoken to Moore about a possible charge of aggravated murder, for which he could be sentenced to death or life without possibility of parole. The state court concluded that Moore had not received ineffective assistance. Moore subsequently sought post-conviction relief in federal court, where the United States District Court for the District of Oregon denied Moore's request on the ground that suppression of the evidence would not have made a difference. On appeal, the U.S. Court of Appeals for the Ninth Circuit reversed, in part, because it found that the state court's conclusion was an "unreasonable" application of Strickland. ${ }^{57}$ The U.S. Supreme Court granted certiorari.

In applying applicable federal law to Moore's case, the Supreme Court concluded that the state court had not made an unreasonable application of either prong of the Strickland test. ${ }^{58}$ As for the first prong of Strickland, the Supreme Court found it was reasonable for the federal district court to accept counsel's justification for his decision to discuss the plea bargain without first filing a motion to suppress Moore's confession to police..$^{59}$ With regard to the second, prejudice prong of Strickland, the Court noted that the "stakes for defendants are high," and defendants may choose to limit the risks by foregoing trial. ${ }^{60}$ What is also notable about the Premo case for our purposes is that the Court recognized the favorable plea decision-Moore had avoided the death penalty or life imprisonment without possibility of parole. ${ }^{61}$

The Premo Court stated that in this type of case, in which the defendant alleges that ineffective assistance prejudiced him in making a plea, it is incorrect to measure prejudice by asking whether it was "clear beyond a reasonable doubt that a rational jury would have

\footnotetext{
53 Id. at 390.

54 Id. at 388,392

55 Premo v. Moore, 562 U.S. 115 (2011).

56 Id. at $118-19$.

57 Id. at $119-20$.

58 Id. at 120 (applying standard of review as required under Antiterrorism and Effective Death Penalty Act of 1996 (AEDPA), 28 U.S.C.A. § 2254(d) (1996)).

59 Id. at 123-24. The Court stated: "Plea bargains are the result of complex negotiations suffused with uncertainty, and defense attorneys must make careful strategic choices in balancing opportunities and risks." Id. at 124

60 Id. at 129.

${ }^{61}$ Premo v. Moore, 562 U.S. 115, 129 (2011).
} 
found the defendant guilty absent the error." ${ }^{" 2}$ Defendants regularly enter pleas "even though there is a significant probability-much more than reasonable doubt-that they would be acquitted if they proceeded to trial." 63 Instead, the appropriate question asks whether there is a "reasonable probability that [the defendant] would not have entered his plea but for his counsel's deficiency." 64 The Court stressed that the plea process brings stability to the criminal justice system, and this process must not be undermined, especially in cases in which witnesses and evidence were never presented to a fact finder. Moore failed to show prejudice. ${ }^{65}$

Two years later, in 2012, the U.S. Supreme Court issued two cases addressing ineffective assistance of counsel claims involving plea bargains: Missouri v. Frye ${ }^{66}$ and Lafler v. Cooper. ${ }^{67}$ In Missouri v. Frye, the defendant, Galin Frye, had been charged with felony driving with a revoked license. ${ }^{68}$ The prosecution had offered two plea deal options, both of which defense counsel had failed to communicate to the defendant, and the offers expired. The defendant had subsequently waived his preliminary hearing and pleaded guilty to the felony charge. There was no underlying plea agreement. ${ }^{69}$

Frye sought post-conviction relief, claiming ineffective assistance of counsel because his attorney had failed to inform him about the plea offers. The district court denied Frye's request for relief, and Frye appealed to the Missouri Court of Appeals. The appellate court reversed, concluding that Frye had satisfied both Strickland prongs. The U.S. Supreme Court granted certiorari. ${ }^{70}$

In a 5-4 decision, the Supreme Court held that defense counsel's performance had been deficient because "defense counsel has the duty to communicate formal offers from the prosecution to accept a plea on terms and conditions that may be favorable to the accused." ${ }^{\prime 1}$ The Supreme Court concluded, however, that the Missouri Court of Appeals' application of the prejudice prong was insufficient because it focused only on whether Frye would have accepted the more favorable terms of the plea agreement. The Supreme Court explained that in cases in which a plea offer has lapsed or been rejected, a defendant must also show that there was "a reasonable probability the plea would have been entered without the prosecution canceling it or the trial court refusing to accept it, if they had the authority to exercise that discretion under state law." ${ }^{\prime 2}$ The Court remanded the case to state court for a determination of whether there was a reasonable probability the prosecutor and judge would have accepted the plea agreement, including whether Missouri law required them to do so. ${ }^{73}$

The dissent, authored by Justice Scalia, rejected Frye's argument that he had a constitutional right to effective assistance of counsel during the plea bargain process. As

62 Id.

$63 / d$.

64 Id.

65 Id. at 132

${ }^{66}$ Missouri v. Frye, 566 U.S. 134 (2012).

67 Lafler v. Cooper, 566 U.S. 156 (2012).

68 Frye, 566 U.S. at 138.

69 Id. at 139.

${ }^{70} \mathrm{ld}$. at $139-40$.

71 Id. at 145.

${ }^{72}$ Missouri v. Frye, 566 U.S. 134, 147 (2012).

73 Id. at 151 
Justice Scalia noted, "Counsel's mistake did not deprive Frye of any substantive or procedural right; only of the opportunity to accept a plea bargain to which he had no entitlement in the first place." ${ }^{74}$ The dissent also called into question the majority's explanation of the Strickland prejudice prong because the review requires a "process of retrospective crystal-ball gazing posing as legal analysis." 75

The U.S. Supreme Court's holding in Frye is significant because the Court established that counsel's failure to communicate a formal plea bargain constituted deficient performance under Strickland. The Court, however, refrained from deciding whether the deficient performance resulted in prejudice. In Frye's companion case, Lafler v. Cooper, the Supreme Court for the first time found prejudice in a case involving ineffective assistance of counsel and plea bargains.

In Lafler, defense counsel had erroneously advised the defendant, Blaine Lafler, to reject a plea offer and had recommended that he take the case to trial; Lafler had followed his attorney's advice. ${ }^{76} \mathrm{~A}$ jury convicted Lafler of multiple charges, including assault with intent to murder. At a post-conviction hearing, the district court denied Lafler's claim of ineffective assistance of counsel, and the Michigan Court of Appeals affirmed. After the Michigan Supreme Court denied Lafler's petition for review, he filed a petition for federal habeas corpus. The federal district court agreed that Lafler had demonstrated ineffective assistance of counsel, and the U.S. Court of Appeals for the Sixth Circuit affirmed. The U.S. Supreme Court granted certiorari. ${ }^{77}$

Because the State conceded that defense counsel's erroneous advice was deficient performance under Strickland, the Supreme Court focused on the second prong-whether the deficient advice regarding the plea offer had resulted in prejudice. In its analysis, the Court emphasized that Lafler was distinguishable from Hill because "the ineffective advice led not to an offer's acceptance but to its rejection." ${ }^{.78}$ The Court held that Lafler demonstrated a reasonable probability that but for defense counsel's erroneous advice, the defendant would have accepted the plea, the prosecution would not have withdrawn the plea, and the court would have accepted the plea. After determining that Lafler satisfied both Strickland requirements, the Supreme Court then looked to the appropriate remedy and concluded that "[t]he correct remedy in these circumstances. . . is to order the State to reoffer the plea agreement." ${ }^{79}$ The Court also noted that "the state trial court can then exercise its discretion in determining whether to vacate the convictions and resentence respondent pursuant to the plea agreement, to vacate only some of the convictions and resentence respondent accordingly, or to leave the convictions and sentence from trial undisturbed." $" 80$

Writing for the dissent, Justice Scalia expressed concerns with the majority's holding because, according to him, the Sixth Amendment is limited to ensuring a full and fair trial and does not apply to the plea bargain process. ${ }^{81}$ Justice Scalia emphasized that a defendant does not have a right to a plea bargain. He was also apprehensive of the remedy

${ }^{74}$ Id. at 152 (Scalia, J., dissenting).

75 Id. at 154.

${ }^{76}$ Lafler v. Cooper, 566 U.S. 156, 166 (2012).

77 Id. at 161-62.

${ }^{78} / d$. at 163.

${ }^{79} / d$. at 174

$80 / d$.

${ }^{81} / d$. at 176 (Scalia, J., dissenting). 
outlined by the majority, namely, that violations of a constitutional right should ever be left to a trial judge's discretion. ${ }^{82}$

The U.S. Supreme Court's finding of prejudice in Lafler, involving the rejection of a plea offer based on counsel's erroneous advice, in a way paved the path for the Court's finding of prejudice in Lee, involving the acceptance of a plea offer based on counsel's erroneous advice. Before Lee, in cases in which a defendant had accepted a plea bargain based on misadvice, the Supreme Court either found no prejudice or remanded the case to state court for a prejudice determination. The Court's holding in Lee is the first time it concluded that a defendant who had entered into a plea bargain based on erroneous advice of counsel satisfied Hill's requirement to show "that there is a reasonable probability that, but for counsel's errors, [the defendant] would not have pleaded guilty and would have insisted on going to trial." 83 This leads to our discussion of Lee.

\section{Lee v. United States: Proving Prejudice}

The defendant in Lee $v$. United States, ${ }^{84}$ Jae Lee, had moved to the United States from South Korea as a teenager in 1982 and had lived in the United States for 35 years as a lawful, permanent resident. As an adult, Lee had owned and operated two restaurants in Tennessee, but he had also become involved in drug-related crimes. Federal law enforcement officers obtained a search warrant for Lee's residence after a confidential informant had reported that Lee had sold the informant certain quantities of ecstasy and hydroponic marijuana over an eight-year period. The search yielded ecstasy, of which Lee admitted ownership. Lee also admitted to giving ecstasy to friends. ${ }^{85}$

Lee was indicted on one count of possessing ecstasy with intent to distribute, in violation of 21 U.S.C. § 841(a)(1). ${ }^{86}$ This crime was an "aggravated felony" under the Immigration and Nationality Act of $1965,{ }^{87}$ for which a noncitizen's conviction mandated deportation. Defense counsel, however, failed to inform Lee of this fact. When Lee entered into plea discussions with the prosecution, he repeatedly asked his attorney whether he would face deportation, but counsel reassured Lee that he would not. Counsel advised Lee that going to trial would be "very risky," that he would receive a lighter sentence if he pleaded guilty, and that the Government could not deport him. After Lee pleaded guilty, the sentencing court imposed a prison sentence of one year and a day. ${ }^{88}$

Upon learning that he would be mandatorily deported after serving his prison sentence, Lee filed a motion to vacate his conviction and sentence due to defense counsel's ineffective assistance. ${ }^{89} \mathrm{At}$ a hearing on the motion, both Lee and defense counsel testified that "deportation was the determinative issue in Lee's decision whether to accept the plea." "90 Defense counsel also indicated that he would have advised Lee to go to trial if he had known that Lee would be deported. Although the federal district court concluded that defense counsel's assistance was deficient, the court found that Lee could not show

82 Lafler v. Cooper, 566 U.S. 156, 180, 184-85 (2012) (Scalia, J. dissenting).

83 Id. at 163 (quoting Hill v. Lockhart, 474 U.S. 52, 59 (1985)).

84 Lee v. United States, 137 S. Ct. 1958 (2017).

85 Lee, 137 S. Ct. at 1962-63.

${ }^{86}$ Comprehensive Drug Abuse Prevention and Control Act of 1970, 21 U.S.C. §§ 801-971 (1970).

87 See 8 U.S.C.A. §§ 1101(a)(43)(B), 1227(a)(2)(A)(iii) (2014).

88 Lee, 137 S. Ct. at 1963.

89 See 28 U.S.C.A § 2255 (2008).

90 Lee v. United States, 137 S. Ct. 1958, 1963 (2017). 
prejudice. The federal district court reasoned that (1) there was "overwhelming evidence of Lee's guilt," (2) a guilty verdict at a jury trial was an "almost certainty," and (3) a conviction at trial would result in a longer prison sentence than the one imposed after Lee's guilty plea. $^{91}$

The U.S. Court of Appeals for the Sixth Circuit affirmed, concluding that Lee failed to show, under Hill, a "reasonable probability that, but for counsel's errors, he would not have pleaded guilty and would have insisted on going to trial." ${ }^{\text {2 }}$ The Sixth Circuit stated that Lee had "no bona fide defense, not even a weak one" and that "no rational defendant charged with a deportable offense and facing overwhelming evidence of guilt would proceed to go to trial rather than take a plea deal with a shorter sentence." 93 The U.S. Supreme Court granted certiorari.

The Supreme Court acknowledged the well-known Strickland test for determining prejudice - a reasonable probability that but for defense counsel's errors, the result of a trial would have been different-but clarified that in a guilty plea case, the focus is the forfeiture of a proceeding. ${ }^{94}$ In other words, a court does not look at whether the result of a trial would have been different from the result of the plea agreement. The question is whether the defendant was prejudiced by the "denial of the entire judicial proceeding ... to which he had a right." 95

Circling back to its language in Hill, the Supreme Court reinforced its declaration that a defendant can show prejudice by showing a 'reasonable probability that, but for counsel's errors, he would not have pleaded guilty and would have insisted on going to trial." ${ }^{\prime 96}$ The Government argued that Lee could not show prejudice because he had no viable defense, surmising that in addition to being convicted at trial, Lee would also have been subject to deportation and a lengthier prison sentence. The Court rejected the notion, however, that a defendant in Lee's position would have to demonstrate that he would have been better off going to trial. ${ }^{97}$ Defense counsel's advice to Lee had had nothing to do with his prospects at trial.

The Supreme Court found defense counsel's error in this case to be comparable to the error in Hill, in that Hill's attorney had given erroneous parole eligibility advice during plea negotiations and Lee's attorney had given erroneous advice concerning the consequences of his guilty plea. ${ }^{98}$ Although the defense's likelihood of success at trial can be a strong indicator of whether a defendant will plead guilty, it is entirely understandable that when faced with similarly dire choices, "even the smallest chance of success at trial may look attractive." 99

Giving courts guidance on how to examine the evidence in terms of prejudice, the Lee Court explained that "[c]ourts should not upset a plea solely because of post hoc assertions from a defendant about how he would have pleaded but for his attorney's deficiencies." ${ }^{100}$

${ }^{91} \mathrm{Id}$. at 1964.

92 Id. (quoting Hill v. Lockhart, 474 U.S. 52, 59 (1985)).

93 ld.

${ }^{94} / d$. at 1964-65.

${ }^{95}$ Id. at 1965 (quoting Roe v. Flores-Ortega, 528 U.S. 470, 483 (2000)).

${ }^{96}$ Lee v. United States, 137 S. Ct. 1958, 1965 (2017) (quoting Hill, 474 U.S. at 59).

${ }^{97} \mathrm{Id}$. at 1965-66.

${ }_{98} / d$. at 1965.

${ }^{99} \mathrm{Id}$. at 1966 .

$100 / d$. at 1967. 
Consequently, it is not enough for a defendant to make after-the-fact assertions because there is a strong societal interest in preserving guilty pleas. Instead, courts should look at whether "contemporaneous evidence" substantiates the defendant's "expressed preferences." ${ }^{101}$ The Court found that substantial and uncontroverted evidence supported Lee's assertion that he would not have accepted a plea if he had known it would result in mandatory deportation. In fact, deportation had been the determinative factor in Lee's decision.

In Justice Thomas's dissent, joined in part by Justice Alito, he opined that the majority departed from the well-established two-part Strickland test by allowing a defendant to show that he would have gone to trial but for counsel's misadvice without also requiring the defendant to demonstrate that "he would likely have obtained a more favorable result in the end." ${ }^{102}$ Looking to past precedent, Justice Thomas noted that in the context of establishing prejudice, the Premo Court had described the prosecution's case as "formidable" and observed that "[t]he bargain counsel struck" with Moore was "a favorable one," contrasted with what might have occurred at trial. ${ }^{103}$ This same effect, according to Justice Thomas, existed in Frye and Lafler, ${ }^{104}$ in which the Court had stated that the prejudice inquiry requires a defendant to establish a "reasonable probability of a different outcome." 105

Justice Thomas predicted that the "decision today will have pernicious consequences for the criminal justice system" and expressed concern that the finality of favorable plea deals is no longer certain, especially in light of defendants' "relatively low burden" to demonstrate prejudice. ${ }^{106}$ As a result, a huge influx of challenges to both past and future plea agreements could occur, arguably counteracting the societal interest in preserving pleas. Justice Thomas criticized the majority's failure to limit its holding to deportation consequences, stating that upcoming cases could allege misadvice on numerous subjects that defendants deem important. ${ }^{107}$

\section{Reflection and Possible Implications of Lee}

The possible implications of Lee are not yet clear. On one hand, as feared by Justice Thomas in the dissent, Lee could open the floodgates for ineffective assistance of counsel claims. ${ }^{108}$ For the first time, the U.S. Supreme Court has found prejudice in a case where a defendant entered into a plea bargain. ${ }^{109}$ Thus, Lee gives defendants additional grounds

101 Id.

102 Lee v. United States, 137 S. Ct. 1958, 1970-71 (2017) (Thomas, J., dissenting).

103 Id. at 1971 (citing Premo v. Moore, 562 U.S. 115, 129 (2011)).

104 Missouri v. Frye, 566 U.S. 134, 147 (2012) (stating that it is "necessary" to show a "reasonable probability that the end result of the criminal process would have been more favorable by reason of a plea to a lesser charge or a sentence of less prison time"); Lafler v. Cooper, 566 U.S. 156, 164 (2012) (stating that a defendant "must show" a reasonable probability that "the conviction or sentence, or both, under the offer's terms would have been less severe than under the judgment and sentence that in fact were imposed").

105 Lee, 137 S. Ct. at 1973-74 (Thomas, J., dissenting).

$106 / d$.

107 Id.

108 Id.

109 See Lafler v. Cooper, 566 U.S. 156 (2012) (finding prejudice where defendant rejected plea agreement based on defense counsel's misadvice). 
to argue ineffective assistance of counsel claims. Approximately $95 \%$ of felony cases in this country end in plea bargains. As such, state and federal courts' application of Lee could cause the criminal justice system to experience significant repercussions. ${ }^{110}$

Because of $L e e$, it is now clear that with respect to an ineffective assistance claim based on defense counsel's advice during plea bargaining, a defendant's likelihood of success at trial is not a relevant factor of consideration. In fact, the Lee Court explicitly rejected the argument that a prejudice determination always requires defendants to show they would have been better off going to trial than to accept the plea. ${ }^{111}$ Granted, the Supreme Court in Hill and Premo stated that a prejudice determination does not always require courts to examine the defendant's likelihood of success at trial, but the Court never delved deeper into this rule in Hill or Premo. The Hill Court did not pursue this line of thought any further because there was no contemporaneous evidence to show that the defendant's acceptance of a plea had been linked to his attorney's misadvice; therefore, this lack of evidence led to the Court's conclusion that Hill could not show prejudice. As for Premo, the Court did look at the defendant's likelihood of success at trial because the defendant's ineffective assistance of counsel claim involved his attorney's misadvice relating to evidentiary trial matters - the failure to seek suppression of the defendant's confession. ${ }^{112}$ Thus, although the Premo Court made the statement that a defendant's success at trial need not always be considered in a prejudice determination, the particular facts in the case dictated the necessity of examining the defendant's likelihood of success at trial. Consequently, although prior to Lee the Court had given lip service to the statement that a prejudice determination need not always include an analysis of trial success, the Court had never applied this rule in a plea bargain case until Lee.

Lee tested whether the Supreme Court was serious about this rule. The extreme facts in Lee demonstrate the extent to which the Court is committed to looking at the basis for a defendant's ineffective assistance of counsel claim when determining what should guide the prejudice analysis. There was little-to-no chance that Lee would have been acquitted at trial. As Justice Thomas noted in his dissent, there was "overwhelming evidence of guilt" against Lee, and Lee lacked a "bona fide defense."113 The Court went so far as to reject the prosecution's request to "adopt a per se rule that a defendant with no viable defense cannot show prejudice from the denial of his right to trial."114

Admittedly, the Supreme Court could have easily discarded Lee's prejudice claim because his likelihood of conviction at trial and subsequent deportation were, at best, "almost certain," but the Court did not do so. ${ }^{115}$ The Court refused to examine the evidence against Lee, emphasizing that his claim of error was "one that affected Lee's understanding of the consequences of the guilty plea." ${ }^{116}$ Because "deportation was the determinative issue in Lee's decision whether to accept the plea deal," the Court limited its evaluation of prejudice to whether Lee would have declined the plea if he had known that accepting the

110 Claire Bernish, Due Process is Dead: A Staggering 95\% of All Inmates in America Have Never Received a Trial, Jan. 25, 2016, http://thefreethoughtproject.com/due-process-dead-staggering-95inmates-america-received-trial/.

${ }^{111}$ Lee v. United States, 137 S. Ct. 1958, 1965 (2017).

112 Premo v. Moore, 562 U.S. 115, 129 (2011).

113 Lee, 137 S. Ct. at 1974 (Thomas, J., dissenting).

114 Id. at 1966.

115 Id. at 1968.

$116 / d$. at 1965. 
plea would "certainly lead to deportation."117 Consequently, despite the damning evidence against Lee, the Court focused not on Lee's prospects at trial but on Lee's understanding of the plea bargain that ultimately circumvented his right to a trial.

Therefore, under Lee, defendants do not have to show that they would have been better off going to trial where their ineffective assistance claims relate not to trial matters but to defendants' understanding of the consequences of a guilty plea. This is not a sharp departure from previous Supreme Court precedent, but this clarification appears to expand the grounds upon which defendants can claim prejudice. By actually finding prejudice in a plea bargain case where the defendant accepted a plea and by clarifying the circumstances under which it is appropriate to consider the possibility of success at trial, the Court seems to have opened the door for finding prejudice. The Court's step forward could arguably lead to new ineffective assistance of counsel claims flooding our judicial system-a system in which the great majority of criminal cases end in a plea bargain. An influx of cases could overload the courts.

On the other hand, despite language in Justice Thomas's dissent suggesting that Lee will likely open the floodgates to claims of ineffective assistance of counsel and corresponding relief for defendants in the context of plea bargains, there is language in Lee that state and federal courts could use to narrowly interpret its holding. First, courts might find Lee distinguishable because the case involved extreme prejudice to the defendant in the form of a deportation consequence. The Supreme Court recognized that deportation was "the determinative factor" in Lee's decision to forego trial and accept the plea. ${ }^{118}$ Lee had repeatedly expressed to defense counsel his concerns about being deported-a dire consequence-and the Supreme Court recognized Lee's insistence that "he would have gambled on trial" if he had known his guilty plea would lead to deportation. ${ }^{119}$ Noting that "deportation is always 'a particularly severe penalty,"' the Court remarked that "preserving the client's right to remain in the United States may be more important to the client than any potential jail sentence." 120 Because of the unique factual situation in Lee, it is possible that other courts will declare that Lee offers relief solely to defendants upon whom immigration consequences fall.

Another reason for a narrow interpretation of Lee is the Supreme Court's insistence that defendants' ineffective assistance of counsel claims cannot be based solely on post hoc assertions. Defendants must point to contemporaneous evidence of their reliance on defense counsel's misadvice in deciding to accept a plea. In Lee, there was no dispute that the defendant's discussions with his attorney during plea negotiations had centered on his deportation concerns, and, thus, there was contemporaneous evidence pointing to his reliance on defense counsel's misadvice regarding immigration laws. Lee's circumstances were contrasted with those in Hill, in which the defendant complained about defense counsel's misadvice about parole eligibility. The Supreme Court observed that Hill had "alleged no special circumstances that might support the conclusion that he placed particular emphasis on his parole eligibility in deciding whether or not to plead guilty."121 Unfortunately, a defendant's after-the-fact claims, akin to buyer's remorse, will not

117 Lee v. United States, 137 S. Ct. 1958, 1967-68 (2017).

118 Id. at 1967.

119 Id. at 1966.

120 Id. at 1968 (quoting Padilla v. Kentucky, 559 U.S. 356, 365, 368 (2010)).

121 Id. at 1965 (quoting Hill v. Lockhart, 474 U.S. 52, 60 (1985)). 
suffice. ${ }^{122}$ These factors-the lack of dire consequences and the lack of contemporaneous evidence-could greatly limit the applicability of Lee.

Ultimately, the full ramifications of Lee are still unknown. The Supreme Court's finding of prejudice in the context of a defendant's acceptance of a plea bargain is significant because the vast majority of criminal cases involve plea agreements. Courts might apply a broad interpretation of Lee, which could lead to an influx of cases into the criminal justice system. This, however, is not a foregone conclusion. It is also possible that Lee's application will be limited because of its unique facts.

\section{Conclusion}

The U.S. Supreme Court's decision in Lee marks a significant step in its recognition of ineffective assistance of counsel claims. There is a question, however, whether the decision will substantially affect future cases. The Supreme Court's contemporaneous evidence requirement could understandably prevent the opening of the floodgates on ineffective assistance claims, but this requirement is quite concerning when looking at the situation from the perspective of criminal defendants. The evidentiary requirement could be problematic for defendants because it is doubtful that most defendants will be able to point to contemporaneous evidence showing that they relied upon counsel's misadvise or were not advised at all about significant consequences of their plea. A large part of the challenge to defendants during the plea-bargaining stage is to make any determinative factor loud and clear, which could be muffled by defendants' lack of knowledge or legal savvy. How can courts expect defendants to be concerned about specific consequences that would be "deal breakers" during plea negotiations if defendants or their attorneys are unaware of or unclear about such concerns in the first place? Moreover, if defense attorneys do offer misadvice, how are defendants expected to recognize the misadvice and conjure up contemporaneous evidence when they do not even know that there is an issue of concern?

It is of great importance that attorneys educate themselves in order to stay current in their knowledge and understanding of the law, even law pertaining to consequences that might be considered collateral to their clients' criminal convictions. In his dissent in Padilla v. Kentucky, Justice Scalia expressed the opinion that there is no constitutional right to effective counsel during the plea-bargaining stage, stating that the "Sixth Amendment guarantees the accused a lawyer 'for his defence [sic]' against a 'criminal prosecution[n]' not for sound advice about the collateral consequences of conviction." ${ }^{123}$ Yet there are reasons to be concerned with what happens during the plea process. Plea bargains are used to circumvent criminal defendants' right to trial. Communications during the pleabargaining stage are largely confidential and involve discussions solely between defendants and their counsel. There is no third party present to monitor the accuracy of the advice given by defense counsel. At least at trial, other members of the criminal justice system, e.g., the judge and prosecutors, are involved in the process, and a record of the proceedings is readily available; these factors provide a layer of protection for defendants that is not present during the plea-bargaining stage. Although criminal defense attorneys routinely deal with legal issues directly related to the criminal prosecution and sentencing requirements, they may nevertheless not be cognizant of all possible consequences of a

122 Id.

123 Padilla v. Kentucky, 559 U.S. 356, 388 (2010) (Scalia, J., dissenting). 
plea deal, including deportation. At a minimum, Lee impresses upon defense attorneys to be proactive and attempt to increase their knowledge and understanding of immigration laws in order to avoid ineffective assistance of counsel issues like those encountered in Lee.

At this point, the measure of Lee's influence is unclear. More research is needed to discover the after-effects of Lee in state and federal courts. Although some of the Court's language in Lee appears to provide hope for relief to criminal defendants who rely on faulty legal advice during the plea process, it is yet to be determined whether that will be the end realized by most defendants. Courts could interpret Lee broadly, but they could just as easily take the opposite approach, interpreting Lee narrowly because of its unique facts. The Supreme Court took a significant step in its holding in Lee. It is yet to be seen whether this step will substantially affect criminal defendants and the criminal justice system.

\section{Declaration of Conflicting Interests}

The author declares no potential conflicts of interest with respect to the research, authorship, and/or publication of this article.

\section{Funding}

The author received no financial support with respect to the research, authorship, and/or publication of this article. 